\title{
THE EXPERIENCE OF SHADOW TEACHERS IN HELPING CHILDREN WTH SPECIAL NEEDS IN TELOGO PATUT ELEMENTARY SCHOOL I GRESIK
}

\author{
Abd. Nasir', Indah Winarni' ${ }^{2}$, Retno Lestari ${ }^{3}$ \\ ${ }^{1}$ Faculty of Vocation, Universitas Airlangga \\ ${ }^{2}$ Faculty of Culture Studies Universitas Brawijaya \\ ${ }^{3}$ Master of Nursing Program, Faculty Of Medicine Universitas Brawijaya
}

\begin{abstract}
Shadow teacher in their profession are always dealing with special needs children who have intellectual impairment, behavioral and emotional disorders and learning disorders. This is an exhausting job because shadow teachers should be able to ensure that the child is always adaptive during the lesson. Shadow teacher also must know how to adapt to the child's character, and this task also spends a lot of time. However, the existence of children in the class is not supported by good learning guidelines. The purpose of this study was to explore the experience of shadow teachers with the child with special needed. This qualitative research used Interpretative phenomenology research design and data analysis used interpretative phenomenology analysis approach. Data collection process used in-depth interviews and observations, and this research involved six participants. This research produced 9 themes: (1) believe that this work is a blessing from Allah, (2) feel that there is a wisdom from helping each others (3) exhausting for mind and emotions, (4) feel not confident at the beginning of his profession, (5) have a feeling that this job is a meaningful job, (6) believe that the children can be disciplined with strict rules, (7) believe that visualization is the way to make children's focus increased, (8) feel that togetherness must be build together with the children, and (9) feel that government and society's concern to these children with special needs is still lacking. Guiding and leading children with special needs is hard to do, but if this job is done with a wholehearted feeling it can make an incredible effort and can make the children with special needs can live peacefully in the middle of society.
\end{abstract}

Keywords: Shadow Teacher, Children with Special Needs, Profession

\begin{abstract}
ABSTRAK
Guru pendamping dalam menjalani profesinya selalu berhadapan dengan anak berkebutuhan khusus yang mengalami gangguan intelektual, gangguan perilaku dan emosi serta gangguan belajar. Hal ini merupakan pekerjaan yang melelahkan karena guru pendamping harus bisa memastikan bahwa anak selalu adaptif selama pembelajaran, beradaptasi dengan berbagai karakter anak, meluangkan banyak waktu. Namun keberadaan anak dikelas kurang didukung dengan pedoman pembelajaran yang jelas. Tujuan penelitian ini untuk mengeksplorasi makna pengalaman guru pendamping anak berkebutuhan khusus dalam menjalani profesinya. Metoda penelitian kualitatif dengan desain penelitian fenomenologi Intepretatif. Analisa data menggunakan pendekatan Interpretative Phenomenology Analysis. Pengumpulan data menggunakan metode wawancara mendalam dan observasi yang melibatkan enam orang partisipan. Penelitian ini menghasilkan 9 tema yaitu yaitu : (1) menganggap pekerjaannya merupakan berkah dari Allah, (2) merasakan ada hikmah membantu sesama, (3) menguras pikiran dan emosi, (4) merasa putus asa di awal menjalani profesinya, (5) merasa apa yang dikerjakan bermakna, (6) meyakini anak bisa disiplin dengan penegakan aturan yang ketat, (7) meyakini cara visualisasi membuat anak mampu memusatkan perhatian, (8) merasa perlu membangun kebersamaan, dan (9) merasa kepedulian pemerintah dan masyarakat masih kurang.Membangun rasa kebersamaan antar guru pendamping perlu dipertahankan dan dilakukan dengan sepenuh hati sehingga menghasilkan prestasi yang luar biasa bagi anak berkebutuhan khusus.
\end{abstract}

Kata Kunci: Guru Pendamping, Anak Berkebutuhan Khusus, Profesi

Jurnal Ilmu Keperawatan, Vol 6, No. 1 Mei 2018; Korespondensi : Abd Nasir. Fakultas Vokasi, Universitas Airlangga. Alamat : Jln. Dharmawangsa Dalam No 28 - 30 (Kampus B) Surabaya 6028. Email : abdoel.nasir@gmail.com 


\section{PENDAHULUAN}

Menjadi guru pendamping bagi anak berkebutuhan khusus, merupakan pekerjaan yang sangat melelahkan. Hal ini oleh karena Anak berkebutuhan khusus berbeda dengan anak lainnya. Anak berkebutuhan khusus mempunyai banyak kekurangan, antara lain menurunnya kondisi fisik, kemampuan intelektual, kemampuan komunikasi dan menurunnya kondisi sosial dan emosional (Lindsay et al, 2013).

Tantangan terbesar yang harus dihadapi guru pendamping adalah guru pendamping dituntut untuk memenuhi capaian keberhasilan pembelajaran bagi anak berkebutuhan khusus, walaupun tanpa pedoman pembelajaran (Oluka et al, 2015). Kondisi lain yang mengganggu adalah kecukupan waktu untuk bertemu dengan anak berkebutuhan khusus. Hal ini dikarenakan seting pembelajaran bagi anak berkebutuhan khusus meliputi pembelajaran individu, pembelajaran kelompok kecil dan pengajaran kerjasama didalam kelas besar yang diberikan oleh guru pendamping (Takala, et al, 2009), sehingga guru pendamping harus banyak meluangkan waktu.

Keberadaan siswa Anak Berkebutuhan Khusus di kelas reguler, mendorong guru pendamping tertantang untuk menciptakan lingkungan pendidikan yang inklusif walaupun tidak mempunyai panduan yang baku dalam menangani anak dengan Anak Berkebutuhan Khusus (Horrocks, et al., 2013). Pendidikan Inklusif yang diberikan oleh guru pendamping menuntut kemampuan kompetensi yang baik serta waktu luang dalam pendampingan yang tidak sedikit, sehingga guru pendamping mempunyai tanggung jawab untuk memainkan peran dalam pendidikan (Strom \& Guilmets, 2015).
Pengkondisian perilaku mandiri untuk anak berkebutuhan khusus di SDN Telogo Patut I Gresik juga tidak memenuhi harapan guru pendamping. Kurangnya kerjasama antara guru pendamping dan keluarga dalam memaksimalkan potensi yang dimiliki oleh anak berkebutuhan khusus menjadi kesulitan tersendiri. Keterbaruan penelitian kali ini adalah peneliti ingin menggali lebih dalam pengalaman guru pendamping yang mendampingi anak berkebutuhan khusus.

\section{METODE}

Penelitian ini menggunakan metode penelitian kualitatif dengan pendekatan Fenomenologi Interpretif. Analisa data menggunakan pendekatan Interpretative Phenomenology Analysis, yang melibatkan enam orang partisipan. Tehnik pengambilan sampel dengan cara purposive sampling yang memenuhi kriteria inklusi yaitu: sampai saat ini masih aktif dan tercatat sebagai guru pendamping di SDN Telogo Patut I Gresik, berusia 35-50 tahun sudah berkeluarga, dengan pertimbangan individu benar-benar telah memasuki fase tanggung jawab (the responsibility stage). Penelitian ini dilakukan di SDN Telogo Patut 1 Kebomas Gresik dan peneliti selesaikan selama empat bulan yakni Maret - Juli 2017

\section{HASIL}

\section{Deskripsi Tema}

1) Tema meyakini pekerjaan sebagai guru pendamping merupakan berkah dari Allah

Tema meyakini bahwa pekerjaan sebagi guru Pendamping adalah berkah dari Allah ini, untuk menjawab tujuan dari mengeksplorasi pemahaman tentang 
memaknai profesi sebagai Guru pendamping bagi anak berkebutuhan khusus. Persepsi yang selama ini berkembang dimasyarakat adalah profesi guru adalah mengajar di sekolah atau mengajar di SLB (Sekolah Luar Biasa), sehingga tidak terpikirkan sama sekali ketika mendapatkan pekerjaan sebagai guru pendamping bagi Anak Berkebutuhan Khusus, kecuali pasrah kepada Allah atas pekerjaan yang diberikan. Mengutip dari pernyataan partisipan penelitian maka didapatkan kalimat berikut :

"saya fikirkan ngajar bahasa jerman pak ternyata itu enggak"

wes ta kamu itu datango kesini" gitu pak,...

“kamu itu ngajarnya gini ngajarnya anak-anak seperti ini ada anak autis...saya kan gak punya kemampuan untuk mengajar anakanak seperti ini.....itu jalannya Allah atau nggak saya nggak tau..." (P1)

2) Tema merasakan ada hikmah membantu sesama

Tema merasakan ada hikmah membantu sesama ini, untuk menjawab tujuan dari mengeksplorasi pemahaman tentang memaknai profesi sebagai guru pendamping bagi anak berkebutuhan khusus. Hanya orang yang hebat yang selalu berfikir ingin menolong anak yang hebat. Dia hanya berharap agar apa yang dilakukan membawa manfaat orang lain dan khususnya berharap agar anak berkebutuhan khusus mendapat perlakuan yang sama di masyarakat, mendapat hak dan kedudukan yang sama dengan anak yang lainnya. Hal tersebut didukung oleh pernyataan partisipan sebagai berikut : "memotivasi saya adalah e...yang pertama saya pengen bermanfaat buat semua... karena anak berkebutuhan khusus ini seringkali dia masih mengalami diskriminasi"(P2)

"...berhadapan dengan anak-anak berkebutuhan khusus itu adalah hal yang sangat baru dan disana saya melihat sepertinya ada manfaat yang luar biasa yang insyaallah bisa saya dapatkan kemudian saya juga ingin memberikan sedikit yang saya tau kepada mereka" (P4)

"waktu itu saya tidak tertarik terus akhirnya...kok tertarik setelah saya siap, e..setelah saya siap saya di rekomkan ngajar disini" (P1)

\section{3) Tema Menguras pikiran dan emosi}

Tema menguras pikiran dan emosi ini, untuk menjawab tujuan dari mengeksplorasi perasaan guru pendamping bagi anak berkebutuhan khusus dalam menjalani profesinya. Sabar ada batasnya. Itulah yang tergambar dari diri seseorang ketika sering menghadapi situasi yang sulit atau menghadapi beban yang bertambah. Hal tersebut didukung oleh pernyataan partisipan sebagai berikut :

"Ya apa ya pak ya ya sedih ya marah ya jengkel, berarti pekerjaan kita bertambah pak padahal kita diruangan kan kita tidak mengawasi dia sendiri ......kasihan mereka juga yang lainnya terbengkalai gitu........... kita masih punya tugas yang lain otomatis tugas yang lain tidak bisa dikerjakan" (P1 dan P2)

\section{4) Tema merasa putus asa}

Tema merasa putus asa ini, untuk menjawab tujuan dari mengeksplorasi 
perasaan guru pendamping bagi anak berkebutuhan khusus dalam menjalani profesinya. Perasaan ini muncul akibat dari ketidakseimbangan antara tuntutan dengan kemampuan yang dimiliki oleh guru pendamping. Hal tersebut didukung oleh pernyataan partisipan sebagai berikut:

"kami akui sebagi manusia kadang-kadang guru juga ada situasi-situasi tertentu ya jadi jenuh jadi bosan karena materi dan situasinya begitu-begitu aja..." (P6)

\section{5) Tema merasa apa yang dikerjakan} bermakna

Tema merasa apa yang dikerjakan bermakna ini, untuk menjawab tujuan dari mengeksplorasi perasaan guru pendamping bagi anak berkebutuhan khusus dalam menjalani profesinya. Ketelatenan dan kesabaran dalam mendidik anak berkebutuhan khusus mampu membangkitkan semangat yang luar biasa dengan diraihnya beberapa juara dan membukakan mata setiap orang terutama guru pendamping bahwa ternyata anak berkebutuhan khusus mempunyai keistimewaan dan keahlian yang bisa membanggakan gurunya maupun institusinya. Hal tersebut didukung oleh pernyataan partisipan sebagai berikut :

“ ...semangat mereka yang luar biasa, terus saya gini, saya melihat itu, saya tidak ada apa-apanya dengan mereka..." (P3)

6) Tema meyakini anak bisa disiplin dengan penegakan aturan yang ketat

Tema meyakini anak bisa disiplin dengan penegakan aturan yang ketat ini, untuk menjawab tujuan dari mengeksplorasi tindakan guru pendamping dalam menjalani profesinya. Menegakkan aturan yang ketat bukan berarti guru pendamping akan semena-mena. Apa yang dilakukan oleh guru hanya mengajari anak berkebutuhan khusus untuk disiplin dengan segala hal terutama perilakunya. Hal tersebut didukung oleh pernyataan partisipan sebagai berikut :

"...kalau autis tidak bisa melakukan itu. Kita buat aturan...untuk melatih anak biar disiplin. Ya berusaha sebisanya untuk menenangkan anak ini...kita buatkan itu tadi time-table waktunya apa jam sekian waktunya belajar ini belajar ini" (P1)

"kita harus tegas ...sekali tidak ya tidak begitu pak..." (P3, P5, P6)

7) Tema Meyakini cara visualisasi membuat anak mampu memusatkan perhatian

Tema Meyakini cara visualisasi membuat anak mampu memusatkan perhatian ini, untuk menjawab tujuan dari mengeksplorasi tindakan guru pendamping dalam menjalani profesinya. Cara visualisasi yang dilakukan oleh guru pendamping terhadap anak berkebutuhan khusus yaitu dengan mengajarkan sesuatu melalui media yang disukai dengan harapan anak bisa berkonsentrasi terhadap apa yang diajarkan. Hal tersebut didukung oleh pernyataan partisipan sebagai berikut :

"...na kita buatkan soal yang besarbesar gitu pak..."(P1. P4)

"kadang-kadang mereka tidak tahu apa yang mereka lakukan dikelasnya itu kita beritahu dengan cara visualisasi seperti itu pak"(P1) 
8) Tema Merasa perlu membangun kebersamaan

Tema merasa perlu membangun kebersamaan ini, untuk menjawab tujuan dari mengeksplorasi tindakan guru pendamping dalam menjalani profesinya. Membangun kebersamaan diantara guru pendamping dilakukan sebagai upaya untuk mempertahankan diri karena merasa dianaktirikan atau kelompok termarginasi. Hal tersebut didukung oleh pernyataan partisipan sebagai berikut :

"kita ini adalah kelompok minoritas kelompok minoritas kita harus bersatu karna untuk mengayomi...karna kalau tidak bersatu program tidak akan jalan....ini kan atas atas komitmen guru-guru bersama... dan alhamdulillah sadar"(P1)

9) Tema merasa kepedulian pemerintah dan masyarakat kurang

Tema merasa kurang diperhatikan ini, untuk menjawab tujuan dari mengeksplorasi hambatan guru pendamping dalam menjalani profesinya. Perhatian pemerintah terhadap fasilitas yang menunjang pembelajaran kurang mendapat respon dari pemerintah, sehingga untuk memenuhi kebutuhan tersebut tidak jarang memaksimalkan kontribusi dari pihak-pihak lain yang terkait terutama dari wali murid yang besarannya tidak mencukupi untuk kelengkapan sarana yang memadai. Hal tersebut didukung oleh pernyataan partisipan sebagai berikut:

“...kalau bisa karena pemerintah itu, ya sekali-kali lah mau datang ke sekolahan_mereka memerlukan apa gitu" (P2, P3)
"Bagi yang honorer itu kan juga harus diperhatikanlah dari pemerintah barang kali ada insentif atau apa gitu loh pak .... khusus guru $A B K$ yang non PNS sampai nangis pak" $(P 3)$

" teman-teman ini masih di gaji dengan gaji yang jauh dari UMR...... itu membutuhkan e...kemampuan khusus na kemampuan khusus ini yang seharusnya dihargai lebih oleh pemerintah, menurut saya" (P5)

\section{0) Keterkaitan Antar Tema}

Guru pendamping dalam memperoleh pekerjaannya didapatkan tanpa disengaja bahkan didapat dari iseng coba-coba mendaftar sekolah jurusan PLB. Ada juga yang mendaftar jadi guru reguler malah diterima sebagai guru pendamping anak berkebutuhan khusus. Hanya dua guru pendamping saja yang sengaja mendaftar jadi guru pendamping akan tetapi keduanya tidak tahu apa yang harus dikerjakan ketika berhadapan dengan anak berkebutuhan khusus. Namun dengan pasrah kepada Allah, guru pendamping bisa bertahan hingga saat ini. Hanya dengan rasa keikhlasan membantu saja dan ada rasa panggilan jiwa saja guru pendamping bertahan hingga saat ini. Namun dalam perjalanannya guru pendamping merasa kepedulian pemerintah dan masyarakat dirasa sangat kurang yang ditandai dengan kurangnya dukungan sarana dan prasarana yang memadai dan tidak ada perhatian kepada nasib guru pendamping, karena hingga saat ini banyak guru pendamping yang statusnya 
non PNS, walaupun masa kerjanya lebih dari 6 tahun. Selain itu intervensi dari masyarakat kepada guru pendamping sering dirasakan kurang menghormati profesinya, karena sering ikut campur dalam penerimaan siswa baru walaupun calon siswa tersebut semestinya tidak di sekolah dasar, melainkan harus masuk SLB karena gengsi. Hal inilah yang membuat guru pendamping merasa putus asa selain apa yang diberikan kepada siswa kurang memberi manfaat bagi perkembangan siswa tersebut. Tidak jarang siswa masih belum bisa calistung (membaca, menulis dan berhitung) walaupun sudah lama menimba ilmu di sekolah. Untuk ibu guru pendamping membuat komitmen bersama untuk tetap memberikan yang terbaik kepada siswanya, saling toleransi dan saling mendukung saat mengatasi anak berkebutuhan khusus bila terjadi gangguan dan emosi. Guru mendamping merasa dengan membangun kebersamaan, masalah kesulitan mendampingi dan mengatasi anak berkebutuhan khusus bisa teratasi. Melalui penegakan aturan yang ketat, anak berkebutuhan khusus dapat disiplin dalam bertingkah laku. Hal ini juga atas kerjasamanya yang baik diantara guru pendamping yang selalu mendukung guru satu dan lainnya. Selain itu untuk bisa anak berkebutuhan khusus mencapai kompetensi akademik, guru pendamping selalu bekerja sama dan saling membantu dalam pengenalan huruf melalui media visualisasi. Guru pendamping saling memberikan informasi yang akurat tentang kemampuan yang dimiliki anak berkebutuhan khusus pada guru lainnya sehingga guru yang baru memberikan materi pelajaran sesuai dari hasil informasi dari guru yang lainnya. Hal inilah yang menguras pikiran dan emosi guru pendamping. Karena upaya yang dilakukan sangat optimal maka guru pendamping merasakan hasilnya dengan pencapaian anak sering mendapatkan juara saat mengikuti kompetisi maupun perlombaan. Hal inilah yang membanggakan guru pendamping.

\section{PEMBAHASAN}

Penelitian ini bertujuan untuk mengeksplorasi Makna Pengalaman Guru Pendamping bagi Anak Berkebutuhan Khusus dalam Menjalani Profesinya di SDN Telogo Patut I Kabupaten Gresik. Sebanyak 6 (enam) partisipan ikut berkontribusi dalam penelitian ini dengan 9 (Sembilan) tema yang berhasil teridentifikasi. Tema pertama membahas guru pendamping meyakini bahwa profesi yang sedang ia jalani sebagai guru pendamping bagi anak berkebutuhan khusus di sekolah Inklusi merupakan karunia Allah. Nilai religius yang ditampilkan menunjukkan sikap kepasrahan diri kepada tuhan untuk menerima segala pemberian Nya. Penelitian yang dilakukan oleh Mukti, D.I., dan Eka Dewi, D.S (2013) menunjukkan keterkaitan antara religiusitas memiliki hubungan dengan penerimaan diri. Dorongan religius tersebut membuat profesi yang dijalani saat ini sebagai guru pendamping anak berkebutuhan khusus tidak bermasalah dengan dirinya sendiri, dan tidak merasa ada beban perasaan terhadap diri sendiri.

Pembahasan tema kedua guru pendamping merasakan ada hikmah 
membantu sesama. Hal ini merupakan pernyataan dari kondisi sejahtera yang diungkapkan guru pendamping dari respon emosi yang baik. Penilaian positif tersebut merujuk pada pendapat dari Diener, et al., (2005) menyatakan bahwa komponen subjective well-being dari afek positif merupakan gambaran pengalaman emosi yang menyenangkan. Respon guru pendamping tersebut mencerminkan respon menyenangkan atau bahagia atas capaian yang selama ini dilakukan. Hasil penelitian ini sejalan dengan penelitian dari Firmansyah, I \& Listyani Widuri, E (2014) bahwa guru pendamping merasa senang atas keberhasilan mengajar, senang atas perkembangan yang dicapai anak didiknya, senang berinteraksi dengan siswa dan tumbuhnya perasaan mencintai siswa.

Tema ketiga menunjukkan bahwa guru pendamping merasakan pikiran dan emosinya terkuras. Hasil penelitian diperoleh bahwa guru pendamping merasa beban pekerjaan yang bertambah karena merasa tugas yang lainnya tidak bisa dikerjakan. Tanoto N (2013) menemukan beberapa kendala anak berkebutuhan khusus sehingga menguras tenaga dan pikiran antara lain bahwa $A B K$ dengan permasalahan berbeda dan memerlukan penanganan yang berbeda, ABK mengalami kesulitan mengikuti materi pelajaran, sikap $A B K$ yang belum bisa mengikuti aturan sehingga mengganggu proses KBM, permasalahan siswa regular terhadap ABK. Banyaknya kendala yang dialami anak berkebutuhan khusus inilah yang membuat guru pendamping mempunyai persepsi yang negative. Hasil penelitian ini selaras dengan hasil penelitian dari Ibnu Ramadhan, $H$ dan Harlina
Nurtjahjanti, H (2017) bahwa terdapat keterkaitan antara persepsi negative terhadap beban kerja. Hal ini menunjukkan bahwa stressor yang tinggi itulah membuat guru pendamping merasa terkuras emosi dan pikiran.

Tema keempat membahas guru pendamping merasa putus asa. Hal ini merupakan bentuk koping yang negative atas respon guru pendamping terhadap anak berkebutuhan khusus dalam menjalani profesinya, dimana tindakannya kurang variatif dengan hasil yang tidak sesuai harapan. Hal ini sejalan dengan hasil penelitian dari Wardhani, D.T (2017) bahwa koping negative semakin meningkatkan burnout bagi guru SLB. Perilaku tersebut akan meningkatkan perasaan bosan sehingga guru pendamping merasa kejenuhan yang luar biasa.

Tema kelima membahas bahwa merasa apa yang dikerjakan bermakna ini. Diener, et al., (2005) menyatakan bahwa komponen subjective well-being dari afek positif merupakan gambaran pengalaman emosi yang menyenangkan. Respon guru pendamping tersebut mencerminkan respon menyenangkan atas tindakan yang diberikan kepada anak berkebutuhan khusus atas capaian yang selama ini dikerjakan. Hasil penelitian ini sejalan dengan penelitian dari Firmansyah, I \& Listyani Widuri, E (2014) bahwa guru pendamping merasa senang atas keberhasilan mengajar, senang berinteraksi dengan siswa dan tumbuhnya perasaan mencintai.

Tema keenam menjelaskan bahwa Guru pendamping meyakini anak bisa disiplin dengan penegakan yang ketat. Pengkondisian operan, menurut Skinner 
(1974) adalah suatu proses memberikan hadiah atas perilaku yang diperankan melalui pemberian penguatan positif sehingga seseorang dapat mengulang maupun mempertahankan perbuatannya atau penguatan negative sehingga perilaku tersebut dapat menghilang sesuai dengan yang diinginkan.

Tema yang ketujuh membahas guru pendamping meyakini bahwa penerapan cara visualisasi membuat anak mampu memusatkan perhatian. Slameto (2010) menyatakan bahwa perhatian adalah kegiatan yang dilakukan seseorang dalam hubungannya dengan pemilihan rangsangan yang datang dari lingkungannya. Hal yang dilakukan oleh guru pendamping dengan media visualisasi adalah agar anak berkebutuhan khusus penglihatannya tertuju pada satu media yang dilihat. Penelitian tersebut didukung oleh hasil penelitian dari Yulis E (2016) dimana hasil penelitian yang didapat menunjukkan bahwa media gambar symbol dapat meningkatkan kemampuan membaca siswa tunagrahita. Hasil penelitian lain dari Rokhimah, R,. Darmawanti, R. 2013 menunjukkan bahwa permainan game yang dapat meningkatkan konsentrasi anak autis.

Tema kedelapan membahas guru pendamping merasa perlu membangun kebersamaan. Hal ini dilakukan oleh guru pendamping sebagai upaya menunjukkan eksistensi diri bagi profesinya agar tidak termarginasi. Hasil penelitian ini sejalan dengan penelitian Isya Luthfi, R et al (2014) yang menunjukkan bahwa hubungan sosial dan kebutuhan pertumbuhan berpengaruh signifikan terhadap variabel kinerja. Keinginan untuk dianggap penting dan sejajar dengan guru regular itulah mendorong guru pendamping untuk membangun kebersamaan diantara sesama.

Tema kesembilan menjelaskan bahwa merasa kepedulian pemerintah dan masyarakat kurang. Hal ini sebagai ungkapan untuk meminta diperhatikan dari pemerintah agar jerih payahnya dihargai dalam meningkatkan motivasi untuk mendidik dan mendampingi anak berkebutuhan khusus. Hasil penelitian ini selaras dengan penelitian dari Febrianti, S., et al (2014) bahwa reward mempunyai kontribusi terhadap motivasi kerja. Dengan perhatian dari pemerintah yang lebih baik lagi, mendorong guru pendamping akan lebih bersemangat untuk lebih meningkatkan kinerjanya.

\section{SIMPULAN}

Landasan utama dalam memberikan pendampingan bagi anak berkebutuhan khusus bagi guru pendamping adalah bahwa pekerjaan yang dijalani merupakan berkah dari tuhan. Saat menjalani profesinya, guru pendamping anak berkebutuhan khusus merasa putus asa. Hal ini oleh karena sebagian besar anak berkebutuhan khusus sulit untuk memusatkan perhatian. Dengan penegakan disiplin yang ketat dan pembelajaran visualisasi, serta didukung dengan rasa kebersamaan yang kuat diantara sesama guru pendamping, anak berkebutuhan khusus dengan cepat mampu memusatkan perhatian, sehingga apa yang telah diperbuat kepada anak berkebutuhan khusus membawa hasil yang baik dan dirasa bermakna.

Saran yang dapat peneliti ajukan adalah sebagai berikut: perlu peningkatan ketrampilan bagi guru pendamping khusus dengan sering mengikuti seminar, dan pelatihan tata cara penangan perilaku anak berkebutuhan khusus. 


\section{DAFTAR PUSTAKA}

Creswell, 2014. Penelitian kualitatif \& Desain Riset. Memilih diantara lima pendekatan. Pustaka Pelajar. Jogjakarta

Diener, Ed., Lucas, R, E., \& Oishi, S. 2005. Subjective well-being: the science of happiness and life satisfaction. New York:

Oxford University Press.

Horrocks, J., White, G., \& Roberts, L. 2008.

Principals' Attitudes Regarding Inclusion Of Children With Autism In Pennsylvania Public Schools. Journal Of Autism And Developmental Disorders, 38, 1462-1473. Ibnu,R.H dan Harlina Nurtjahjanti, H 2017. Hubungan antara Persepsi terhadap Beban Kerja dengan Cyberloafing pada Karyawan Biro Administrasi Umum \& Keuangan Universitas Diponegoro. Jurnal Empati, Volume 6(1), 215-220

Isya Luthfi, R., Heru Susilo, H., Faisal Riza, M 2014. Pengaruh Motivasi Terhadap Kinerja Karyawan. Jurnal Administrasi Bisnis (JAB). Vol. 13 No. 1

Lindsay, S., \& Edwards, A. 2013. A Systematic Review of Disability Awareness Interventions For Children And Youth. Disability \& Rehabilitation. Early Online: 1-24 @ 2012 Informa UK, Ltd. ISSN 09638288 print/ISSN $1464-5165$ online DOI: $10.3109 / 09638288.2012 .702850$

Lindsay, S, Proulx, M., Thomson, N., \& Helen Scott, 2013. Educators' Challenges of Including Children with Autism Spectrum Disorder in Mainstream Classrooms. International Journal of Disability, Development and Education, Vol. 60, No. 4, 347-362, http://dx.doi.org/ 10.1080/1034912X.2013.846470
Mukti, D.I., dan Eka Dewi, D.S (2013). Hubungan Antara Religiusitas dengan Penerimaan Diri pada Pasien Stroke Iskemik Di RSUD Banjarnegara. Psycho Idea, No.2, ISSN 1693-1076

Oluka B.N., \& Eke, N,A, 2015. Managing Children with Learning Disabilities in Inclusive Classroom: Roles of Guidance/ Counsellors. Journal of Educational Policy and Entrepreneurial Research (JEPER) ISSN: 2408-770X (Print), ISSN: 2408-6231 (Online) Vol.2, N0.2, Pp 53-59

Rokhimah, R, Darmawanti, R. 2013. Pengaruh permainan lasy terhadap peningkatan konsentrasi pada anak autis. Jurnal Psikologi \& Terapan, Vol 4 No. 1, 48 - 55 Slameto. 2010. Belajar \& Faktor-Faktor yang mempengaruhi. Jakarta: Rineka Cipta

Suran, S.G and Rizzo J. (1979). Being Deaf : The Experience of Deafnes. London: Pinter Press

Takala, M., Pirttimaa, R., Tormanen, M. 2009. Inclusive special education: the role of special education teachers in Finland. British Journal of Special DOI: 10.1111/ j.1467-8578.2009.00432.x

Tarnoto N 2016. Permasalahan-Permasalahan yang Dihadapi Sekolah Penyelenggara Pendidikan Inklusi pada Tingkat SD. Humanitas (Jurnal Psikologi Indonesia) Vol 13, No 1: 50-61. ISSN 1693-7236

Yulis E. 2016. Upaya Peningkatan Kemampuan Membaca Melalui Media Gambar Simbol Untuk Anak Tunagrahita Sedang. Jurnal Konseling dan Pendidikan. ISSN Cetak:23376740. http://jurnal. konselingindonesia. com. Volume 4 Nomor 3

Zakia, D.L. 2015. Guru Pembimbing Khusus (GPK): Pilar Pendidikan Inklusi. Prosiding Seminar Nasional Pendidikan ISBN: 978979-3456-52-2 